\title{
Employment Obtaining and Business Starting
}

\author{
Jian Lan \\ Department of Mechanical and Electrical Engineering \\ Beijing Polytechnic College \\ No.368, Shimen Road, Shijing Shan District \\ Beijing 100042, China \\ Tel: 86-10-5151-1049 E-mail: lanhuahua414@126.com
}

\begin{abstract}
The implementation of business starting education in higher vocational colleges is of important and realistic meanings for cultivating advanced technology application-type talents and for releasing the employment obtaining pressure of higher vocational students. Based on the analysis on the employment situation of higher vocational graduates, this paper explores the thoughts and methods for higher vocational colleges to implement business starting education.
\end{abstract}

Keywords: Higher vocational colleges, Employment obtaining, Business starting education

\section{The connotations of business starting education}

Business starting education refers to the education that aims at developing and improving business starting capacities of students and cultivating students' capacity of the awareness, spirit, quality, and knowledge needed in business starting activities. This education actually aims at educating students to become business starting persons thought setting up business starting awareness, cultivating business starting spirit and quality, teaching business starting knowledge and forming business starting capacity ( $\mathrm{Li}, 2007)$. To put it in other ways, the essential of business starting education is a type of comprehensive education mode, which cultivates students' business starting awareness, business starting spirit, business starting quality, business starting knowledge and business starting capacity. Business staring education improves students' ability to find job opportunity themselves and cultivating talents for the society who have comprehensive capacities, including innovation ability, risk taking ability, healthy psychology, independent working ability, collaboration and cooperation ability, social communication and management ability (Guo, 2007).

\section{The current employment situation of higher vocational graduates in China}

\subsection{Universities enlarge enrollment in successive years, pricking up employment pressure}

With the continuous reform and development of China's education, higher education has transformed from talent education to common education, which is mainly shown in the large scale enrollment extension of universities in 1999. According to rough statistics, in 1960s, the annual national student enrollment remained at 150 thousands. However, after entering the $21^{\text {st }}$ century, the students enrollment scales extends rapidly and the annual students enrollment reaches 4500 thousands. After the students enrollment enlargement, graduates increase every year, resulting in hardship for students to obtain employment (Guo, 2007).

\subsection{Traditional value concept influences the employment of higher vocational graduates}

Due to the traditional concept, the majority of students, including their parents, hope to engage in administration and management after graduation and become "white collar" and would not like to engage in technology work and to become "blue collar". Besides, for a long time, China's education structure lacks for scientific nature. China's education emphasizes theory, but not practice and emphasizes universities, but not vocational colleges, resulting in the severe unbalance of supply and demand of social talents. The current social demand is that for one aspect, the supply for social administration field exceeds demand. Some talents could not find jobs. For another aspect, the demand of technology field is higher than the supply. Some posts could not find proper talents. The reason for such situation is that graduates from universities scramble for administration posts and would not like to work on technology posts. Most students of higher vocational colleges and their parents also have such intention. They would rather "discard' their majors and squeeze into administration field. For these reasons, technology posts lack for talents and many students fight for social administration posts.

\subsection{Compared with university graduates, higher vocational graduates have no superiority}

Different from universities which aim at cultivating knowledge and theory type students, higher vocational colleges aim 
at cultivating technology talents who have special skills and are ready to work. Therefore, there is no problem for higher vocational graduates to work on professional technology posts. However, the current situation is that many units and companies, due to long-formed value concept, still prefer university graduates. They would rather to employ university graduates who do not have professional skills or who have weak professional skills and then provide training to them than to employee vocational students who have professional skills. In addition, many vocational graduates seek to find jobs beyond their ability, resulting in their unemployment and the hardship for the development of vocational colleges. If to survive and develop in the environment where there are many universities, higher vocational colleges must face objective reality, exert their advantage according to their features, and combine job-selection with business starting education so as to enlarge the employment channel of their graduates.

\section{Comparison between employment obtaining education and business starting education}

Employment obtaining education takes students' employment as the basic aim and help students to master certain cultural knowledge and won skillful professional ability and necessary common skills as well as some other major skills and be bale to work in certain occupational posts. Such education form could date back to the days after planned economy period and opening up and reform when the jobs of all graduates were to be appointed by the state. This traditional employment obtaining education, together with the lagging back of educational system reform, shows more and more obvious defects (Xu, 2007). For example, in traditional employment obtaining education mode, college students study certain major and skills for engaging in the future occupation. Employment becomes their only aim for receiving education. We could say that college students study for employment. If so, college students are not active in positioning their occupation fate. In addition, the major and skills of college students are limited. Generally speaking, the course design of their specialty has strong parochialism. It is mainly show in that the course contents are repeated and old. Hence, the makings of students are single. Besides their specialties, their do not know other knowledge. But what the market economy demands are the compound talents, or multi-skill talents at the least. Students receiving employment obtaining education could be not adjusted to the social demands.

Although employment obtaining education has some defects, we could not say that we do not need employment obtaining education. What we should focus is how to perfect employment education reform and at the same time, how to bring in business starting education to complement the defects of employment obtaining education. Compared with traditional employment obtaining education, business starting education does not directly help students to find posts. Rather, it emphasizes to teach students to search for or create work posts. To implement business starting education is good for promoting the employment of higher vocational graduate (Yan, 2007). The advantages it has include: it is good for cultivating the personality, innovative thinking, business starting making and capacity. On site base, school sponsored factory and school-enterprise units provide students with stage to test their knowledge and capacity and to show their ability and could also help students to understand the characteristics of the industry, organizational structure and operation methods, increase their industry knowledge and master certain business starting process and promote students to generate business starting awareness and passion and fix business starting aim. It is also good for cultivating students to have tough working style and spirit. Through practice, students could feel the hardship in business starting. In their own business starting process, they could create a world that belongs to themselves. It is also helpful to cultivate the healthy business starting psychology of students. Through business starting education, students could be cultivated to think independently, to make decisions for themselves, to be good at communication and cooperation so that students could have a positive mood to treat their work and life pressure and could have healthy business starting psychology, promote self-adjustment, and keep good psychology so as to adjust to the changing society.

In all, higher vocational colleges shall, according to their actual situation, reasonably set up and start employment obtaining education and business starting education at the same time and make use of their advantage. Based on traditional employment obtaining education, schools shall boldly start business starting education, to supplement the two kinds of education modes.

\section{How higher vocational colleges implement business starting education}

\subsection{Seize the chance and boldly develop business starting education}

Although the business starting education of China starts late and is in the period of trying and exploring, the development of it is rather rapid and it has accumulated certain experience. Considering the experience of developed countries, we could know that to start business starting education on students is a necessary choice for China's higher education. Seeing from professional education, compared with common universities, higher vocational colleges are more tend to skill cultivation, which makes a solid foundation for higher vocational schools to start business starting education. What is more, the business starting education of China is not fixed. Universities could, according to their actual conditions, explore their thoughts and find a most suitable way. Therefore, higher vocational colleges shall seize the change and boldly develop business starting education, update education concept, reform education methods, and change education mode so as to build brand, create feature, build fame and find a position in the reform development tide. 


\subsection{Set up scientific and reasonable business starting education course system}

In China, although some universities have set up business starting education, the course system is not mature. But higher vocational colleges do. However, generally, higher vocational colleges have practice base and cooperation enterprises of long term relationship. They should make use of this advantage to create a series of course system. This course system shall focus on cultivating the business starting spirit and ability of students and set up teaching actives according to this focus, including enterprise management, risk investment, business starting financial basis and market investigation methods. At the same time, schools should teach students knowledge on finance, financing, tax, marketing, and business affairs and invite successful persons to give lectures and forums. Different from traditional theory education, business starting education shall enlarge the percentage that experiments, practice and social practice account for and encourage students to go out of classes and to touch and feel the society. Through the many out-of-class activities and social practices, we could enhance students' ability to obtain knowledge and think about problems. By this way, we could cultivate students into the compound talents who have wide vision, are active in innovation and dare to practice.

\subsection{Found a teaching team for business starting education}

Whether business starting education could be smoothly developed and popularized in China, professional teachers are important. At present, most of teachers of universities that start business starting education only have theory teaching experience and have no or lack for practice experience. Because they do not have business starting experience, what they teach is mostly theoretical knowledge and is not practice knowledge. It is easy to put business starting education into a form education. Universities could retain their schoolfellows that have successfully started business, social business starting models, enterprisers and experts who have experience in business starting to come to schools and give lectures on business starting and spread business starting concepts. At the same time, schools should also actively encourage their teachers to go to enterprises and experience themselves business starting process and accumulate their business starting experience. Also, schools could also form business starting leagues and invite professionals to become guide teachers. We could start to simulate business starting practice among students through activities.

In all, business starting education is a brand new education way. It is also a systematic project that involves the entire society and needs the support from society, government, schools, enterprises and families. In the social environment, the governments shall make preferential policies for business starting education and open green channel so as to help it to develop. Schools shall continuously explore the methods for business starting education, form scientific and reasonable course system, build a special teaching team, finally set up teachers base so as to optimize and reasonable share resources. Enterprises shall exert important functions in the practice state of business starting education. They shall not only provide excellent teachers, but all provide practice site for students. Families shall also need to support business starting education. For one hand, they should change their concepts. For another concept, they shall provide support for students. Besides, we could also actively learn the advanced experience and outcomes from foreign countries. By these ways, we could explore a road for the development of business starting education that suits China's situation.

\section{References}

Guo, Yankun. (2007). Discussion on business starting education in higher vocational colleges. Commercial Economy. (8):118-119.

Li, Xia. (2007). A probe into the business starting education of higher vocational students. Scientific and Technological Information. (28):173.

$\mathrm{Xu}$, Wei. (2007). Thoughts on the transition of higher vocational colleges from employment obtaining education to business starting education. The Road of Growth. (2):1.

Yan, Xuan \& Cao, Huaxia. (2007). Thoughts on the implementation of business starting education in higher vocational colleges. Shanxi Higher School Social Science Paper. (19)8:97-99. 